Research Article

\title{
Cramming the Specificities in Contemplating Safe Bearing Capacity for the Foundation Assessed from Borehole Samples in a Sandy-Moorum Zone
}

\author{
Tarun Kumar Lohani ${ }^{D}{ }^{1},{ }^{1}$ Melkamu Teshome Ayana $\left(\mathbb{D},{ }^{1}\right.$ \\ Abdella Kemal Mohammed $\left(\mathbb{D},{ }^{1}\right.$ and Jyotiranjan Pattanaik ${ }^{2}$ \\ ${ }^{1}$ Department of Hydraulic and Water Resources Engineering, Arba Minch Water Technology Institute, Arbaminch, Ethiopia \\ ${ }^{2}$ Senior Engineer Planning, M/S Sobha Limited, Bhubaneswar, India \\ Correspondence should be addressed to Melkamu Teshome Ayana; melktesh@gmail.com
}

Received 12 November 2020; Revised 3 May 2021; Accepted 27 June 2021; Published 7 July 2021

Academic Editor: Emanuele Brunesi

Copyright (C) 2021 Tarun Kumar Lohani et al. This is an open access article distributed under the Creative Commons Attribution License, which permits unrestricted use, distribution, and reproduction in any medium, provided the original work is properly cited.

\begin{abstract}
Borehole samples drilled up to a depth of $10 \mathrm{~m}$ provide a clear understanding whether a foundation is safe for any structure. The main objective of the present study reconnoitered the soil bearing capacity and foundation settlement characteristics using the standard penetration test (SPT) data obtained from 3 boreholes at $1 \mathrm{~m}, 2 \mathrm{~m}$, and $3 \mathrm{~m}$ depths to correlate soil properties and deterrents, if any, created by groundwater. The methodology of the research is to collect soil samples, and ensuing subsoil analysis was performed in order to obtain concrete information to optimize the foundation system within the safe bearing capacity of soil and its allowable settlement. The scope of the work encompasses conducting detailed soil investigation from drilling logs, laboratory testing, and conducting and estimating safe bearing capacity. The result of the research aims at providing safety to the foundation from the investigations of conclusive recommendation to be adopted which would be economically feasible and structurally secured.
\end{abstract}

\section{Introduction}

Geotechnical investigations known as site investigation include surface and subsurface explorations of a site which are performed to acquire information on physical properties of the soil and rock around the area of Jayadev Vihar in Bhubaneswar of eastern India so as to justify the soil quality for safe foundation. In many instances, it has been recorded that due to diverse soil characteristics in nature, structures may result in collapse by virtue of uneven settlement and tilting [1-3]. Subsurface exploration usually involves soil sampling and laboratory tests of the soil samples retrieved. Subsoil investigation and subsequently studying the character of strata are essentially required to determine the bearing capacity of the foundation soil at different depths in $\mathrm{m}$ with safety and reliability of the structure depending on the foundation of the structure [4]. The planning of the structure and ensuing design and implementation are dependent on soil investigation of founding strata followed by the quality of execution and postconstruction maintenance. Use of smart technologies for such investigation has become a common procedure adopted by various organizations [5-13]. External load adhered to the foundation increases the compressive stress on soil which leads to the settlement of foundation [14]. Standard penetration test (SPT) is the most popular in situ test experiment used to evaluate the strength of soil [15]. Even in developed countries, $85 \%$ to $90 \%$ of conventional foundation design is conducted using SPT results [16]. Kulhawy and Mayne [17] proposed to use the SPT data in correlations for unit weight, relative density, angle of internal friction, and unconfined compressive strength which are most popular, useful, and economically adopted all over the world [18]. Many research studies have been accomplished till date on various geologic formations, 
TABLE 1: Safe bearing pressure of borehole samples.

\begin{tabular}{|c|c|c|c|c|c|c|c|}
\hline \multirow[b]{2}{*}{$\begin{array}{l}\text { Borehole } \\
\text { no. }\end{array}$} & \multirow[b]{2}{*}{$\begin{array}{l}\text { Depth } \\
(\mathrm{m})\end{array}$} & \multirow[b]{2}{*}{$\begin{array}{l}\text { Type of } \\
\text { sample }\end{array}$} & \multicolumn{3}{|c|}{ Square footing $(2.0 \mathrm{~m} \times 2.0 \mathrm{~m})$} & \multirow[b]{2}{*}{$\begin{array}{l}\text { Settlement } \\
\quad(\mathrm{mm})\end{array}$} & \multirow[b]{2}{*}{$\begin{array}{l}\text { Safe bearing pressure } \\
\text { (SBP) } \\
\left(\mathrm{T} / \mathrm{m}^{2} \text { for } 50 \mathrm{~mm}\right. \\
\text { settlement })\end{array}$} \\
\hline & & & $\begin{array}{c}\mathrm{SPT} \text { “ } N \text { ” } \\
\text { value }\end{array}$ & $\begin{array}{c}\text { Net safe bearing } \\
\text { capacity (NSBC) } \\
\left(\mathrm{T} / \mathrm{m}^{2}\right)\end{array}$ & $\begin{array}{c}\text { Safe bearing } \\
\text { capacity }(\mathrm{SBC}) \\
\left(\mathrm{T} / \mathrm{m}^{2}\right)\end{array}$ & & \\
\hline \multirow{3}{*}{1} & 1 & SPT & 30 & 13.81 & 14.81 & 24 & 28.77 \\
\hline & 2 & SPT & 34 & 27.2 & 29.2 & 35 & 38.86 \\
\hline & 3 & SPT & 39 & 54.83 & 57.83 & 55 & 49.85 \\
\hline \multirow{3}{*}{2} & 1 & SPT & 32 & 17.34 & 18.34 & 29 & 29.9 \\
\hline & 2 & SPT & 35 & 33.88 & 35.88 & 39 & 43.44 \\
\hline & 3 & SPT & $>50$ & 80.87 & 83.87 & 64 & 63.18 \\
\hline \multirow{3}{*}{3} & 1 & SPT & 27 & 14.81 & 15.81 & 26 & 27.27 \\
\hline & 2 & SPT & 31 & 26.51 & 28.51 & 38 & 34.88 \\
\hline & 3 & SPT & 37 & 54.83 & 57.83 & 57 & 48.1 \\
\hline
\end{tabular}

but initiation has been taken to find safe bearing capacity of the soil specifically composed of laterites and that too of sedimentary origin.

\section{Materials and Methodology}

Design of shallow foundations on granular soils of the study area does not account for the absolute size of the footing or the scale effect between the soil and the foundation [19]. As per the site visit, it was noticed that the soil is mostly granular hence proceeding further; three boreholes were carried out mechanically using power-operated mechanical boring in normal strata and diamond cutter in hard strata up to $10 \mathrm{~m}$ below the natural ground level (NGL) or refusal as per [20]. Standard penetration test (SPT) using the split spoon sampler as per [21] was carried out from the ground level at every alternative $1 \mathrm{~m}$ and $2 \mathrm{~m}$ interval up to $10 \mathrm{~m}$ depth. The SPT sampler was lowered inside the borehole after drilling the required level and was driven by a $63 \mathrm{~kg}$ hammer with a free fall of $75 \mathrm{~cm}$ in three stages, $15 \mathrm{~cm}$ each, and the number of blows for each $15 \mathrm{~cm}$ penetration for the 2nd and $3 \mathrm{rd} 15 \mathrm{~cm}$ drive was taken together as the field " $N$ " value or the standard penetration resistance of the soil. Refusal is considered for $N>100$ [22]. In the course of drilling, groundwater was encountered at a depth of $1.2 \mathrm{~m}$ to $1.4 \mathrm{~m}$ NGL. After the penetration to full depth, the sampler was carefully pulled out followed by the removal of cutting shoe and head. The soil samples were then sealed in polythene bags and labeled properly by indicating the depths, borehole mark, and reference number for visual inspection and identification of soil samples for logging of boreholes and were carefully transported to the laboratory for testing purpose. The laboratory tests were conducted on selected representative disturbed/SPT soil samples collected from different boreholes drilled. The tests include grain size analysis, natural moisture content, DFS, specific gravity and liquid limit, plastic limit, plasticity index, and particle size distribution on representative soil samples. The grain size analysis of different soil samples was conducted as per the requirement of [23]. The results of grain size analysis were used to classify the soil in various depths of boreholes. The natural moisture content was determined from undisturbed samples of different boreholes at various depths, as per [24].
It is used for determining specific gravity, optimum moisture content, S.B.C, and settlement of the foundation system. The specific gravity of the SPT/DS samples has been determined at different levels as per [25]. It is used for determining void ratio, porosity, saturated density, S.B.C, and settlement of the foundation system. The liquid and plastic limits including other index properties of the soil were also determined as per [26] code of practice and were used for determining S.B.C, settlement of the foundation system, and associated characters. DFS test which determines the swell index of the soil in order to identify the potential of the soil to swell was conducted as per [27].

2.1. Objectives of the Subsoil Exploration. The calculation of bearing capacity has been adopted [28], providing the equation for the net ultimate bearing capacity, the width of footing $\left(W^{\prime}\right)$, the depth of footing $\left(D_{f}\right)$, the length-to-width ratio $(\mathrm{L} / \mathrm{B})$, the field density $(\Upsilon)$, and the angle of shearing resistance $\left(\Phi^{\prime}\right)$ :

$$
q u=c N_{c} S_{c} d_{c} i_{c}+q\left(N_{q}-1\right) S_{q} d_{q} i_{q}+0.5_{\Upsilon} B N_{\Upsilon} S_{\Upsilon} d_{\Upsilon} i_{\Upsilon} W^{\prime},
$$

where $q$ is the effective pressure at the base. by

The second term has been changed because $q_{\text {ult }}$ is given

$$
\begin{aligned}
Q_{n u} & =q_{u}-\Upsilon, \\
D_{f} & =q_{u}-q .
\end{aligned}
$$

The factor $W^{\prime}$ takes into account the effect of the water table. If the water table is at or below a depth of $\left(D_{f}+B\right)$, measured from the ground surface, $W^{\prime}=1.0$. As the water table is likely to rise to the base of the footing or above, the value of $W^{\prime}$ is taken as 0.50 . If the water table is located at a depth $D$ below the ground surface, $D_{f}<D<100$. And $d_{q}=d_{\Upsilon}=1+0.1\left(D_{f} / B\right) \tan \left(45^{\circ}+\Phi^{\prime} / 2\right)$. The objective of this geotechnical investigation is to optimize the foundation system for within the safe bearing capacity of the soil and allowable settlement which consists of the following:

(1) Determination of type, size, and depth of the foundation system by analyzing the soil properties 


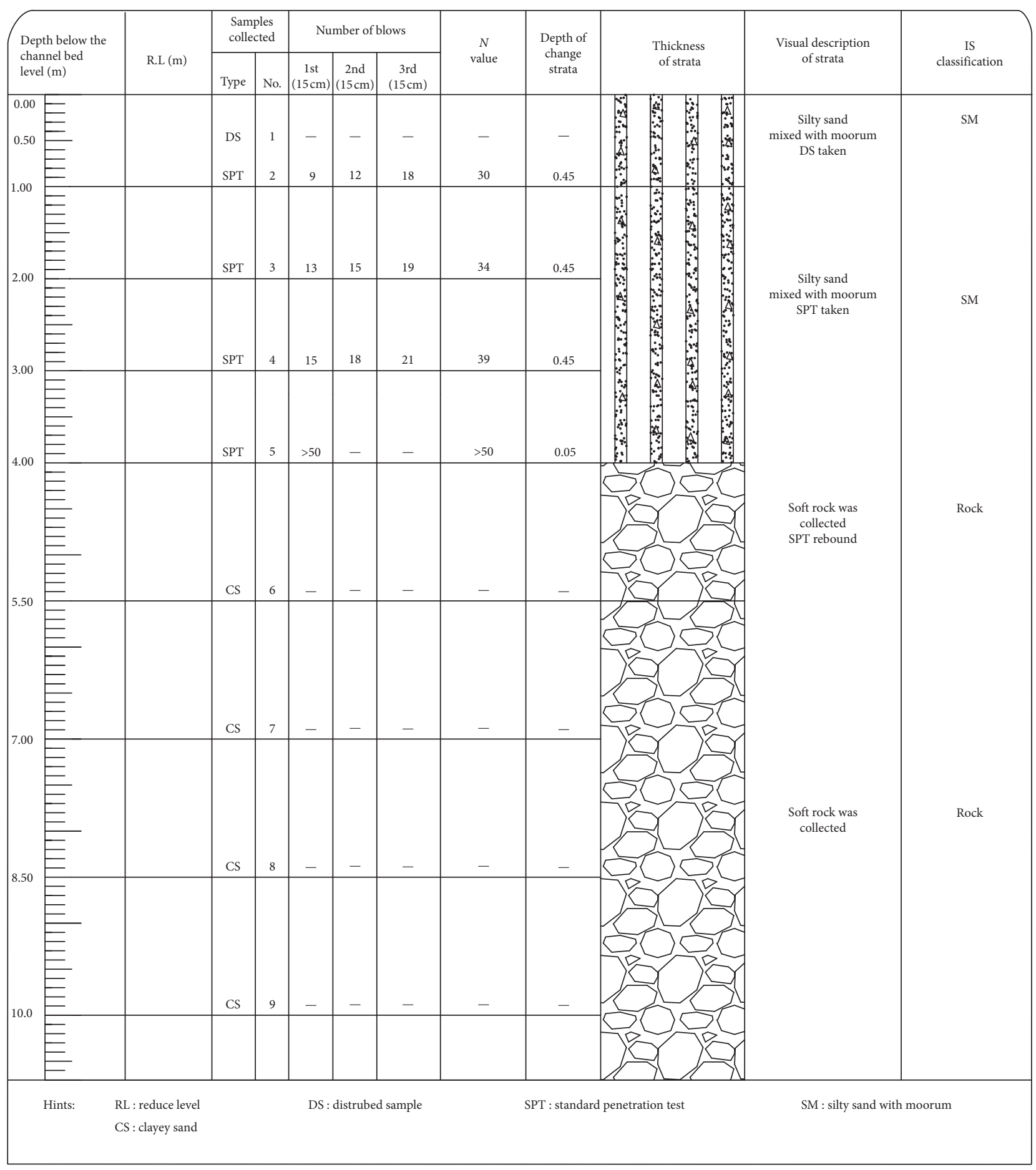

Figure 1: Log datasheet of borehole 1.

(2) To suggest a conclusive recommendation for the type of foundation system to be adopted which would be economically viable and structurally safe for the proposed structures of the projects

2.2. Nature of Investigation Work. The overall investigation consists of the following:

(i) Visual reconnaissance of the site. (ii) Field work drilling of boreholes up to the required depth.

(iii) Laboratory experiments and determination of soil parameters.

(iv) Analysis of the field and laboratory data.

(v) Arriving at the conclusive decision on the foundation system to be adopted in the present case using engineering judgment, based on the current 


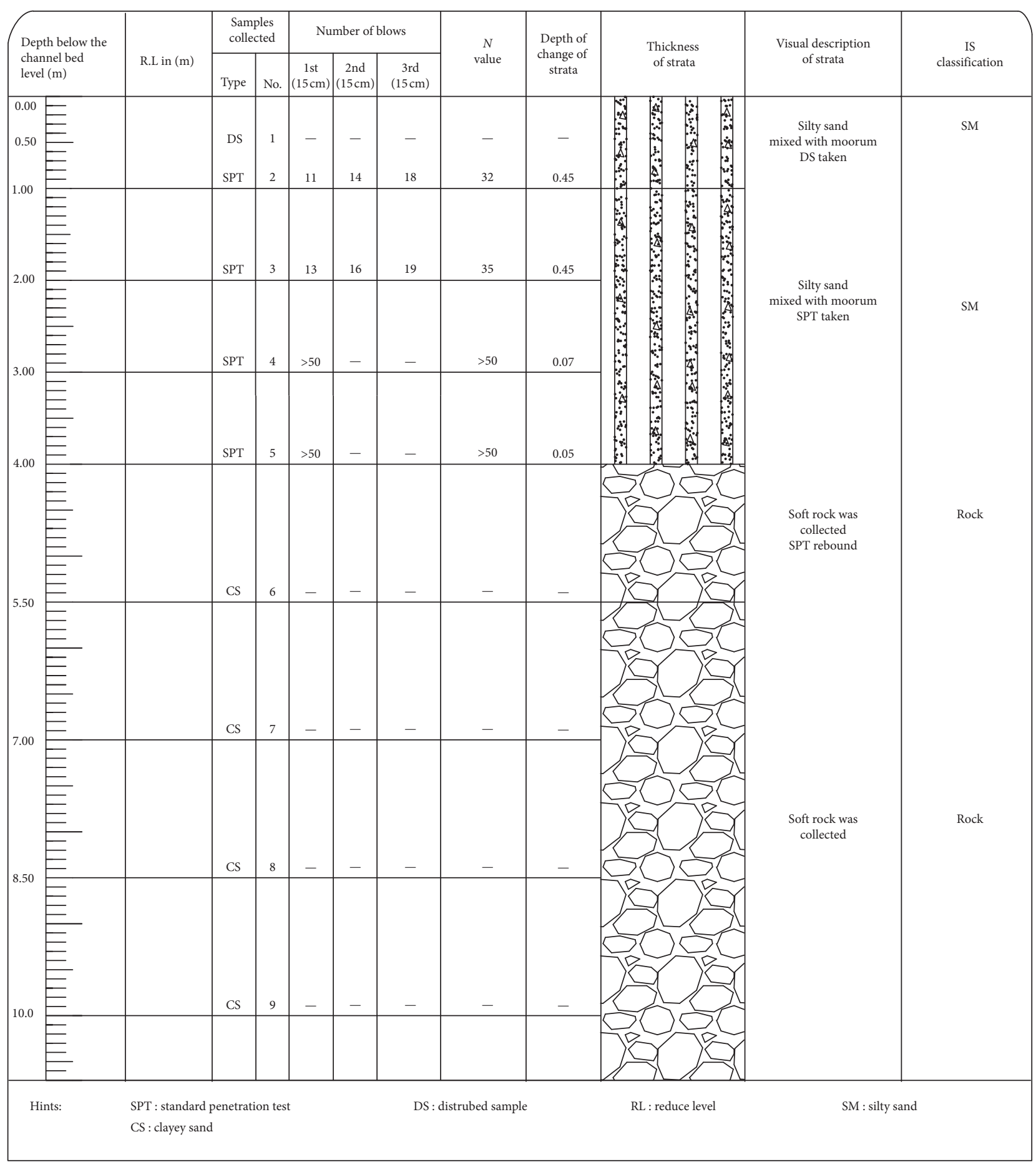

FIgURE 2: Log datasheet of borehole 2.

practice. The detailed geotechnical investigation work that was carried out consists of two parts.

\section{Results and Discussion}

Accordingly, the geotechnical investigation was carried out both in the field and laboratory to know the subsoil character and different engineering properties met at different depths. The " $N$ " values recorded at various depths have been reported in Table 1.
The analysis of the subsurface investigation test result of the soil samples from the 1st borehole ( $\mathrm{BH}-1)$ collected during boring for the geotechnical investigation work (Figure 1) concludes that, from $0.0 \mathrm{~m}$ to $4.0 \mathrm{~m}$ depth, nonplastic, nonexpansive silty sand mixed with moorum strata was present. DS was collected at $0.5 \mathrm{~m}$, and field $N$ value was from SPTs 30, 34, and 39 at $0.5 \mathrm{~m}, 1.0 \mathrm{~m}, 2.0 \mathrm{~m}$, and $3.0 \mathrm{~m}$ respective depths. The existence of soft rock strata was found from $4.0 \mathrm{~m}$ to $10.0 \mathrm{~m}$ depth. In the 2 nd borehole $(\mathrm{BH}-$ 2), from $0.0 \mathrm{~m}$ to $4.0 \mathrm{~m}$ depth (Figure 2), it has been noted 


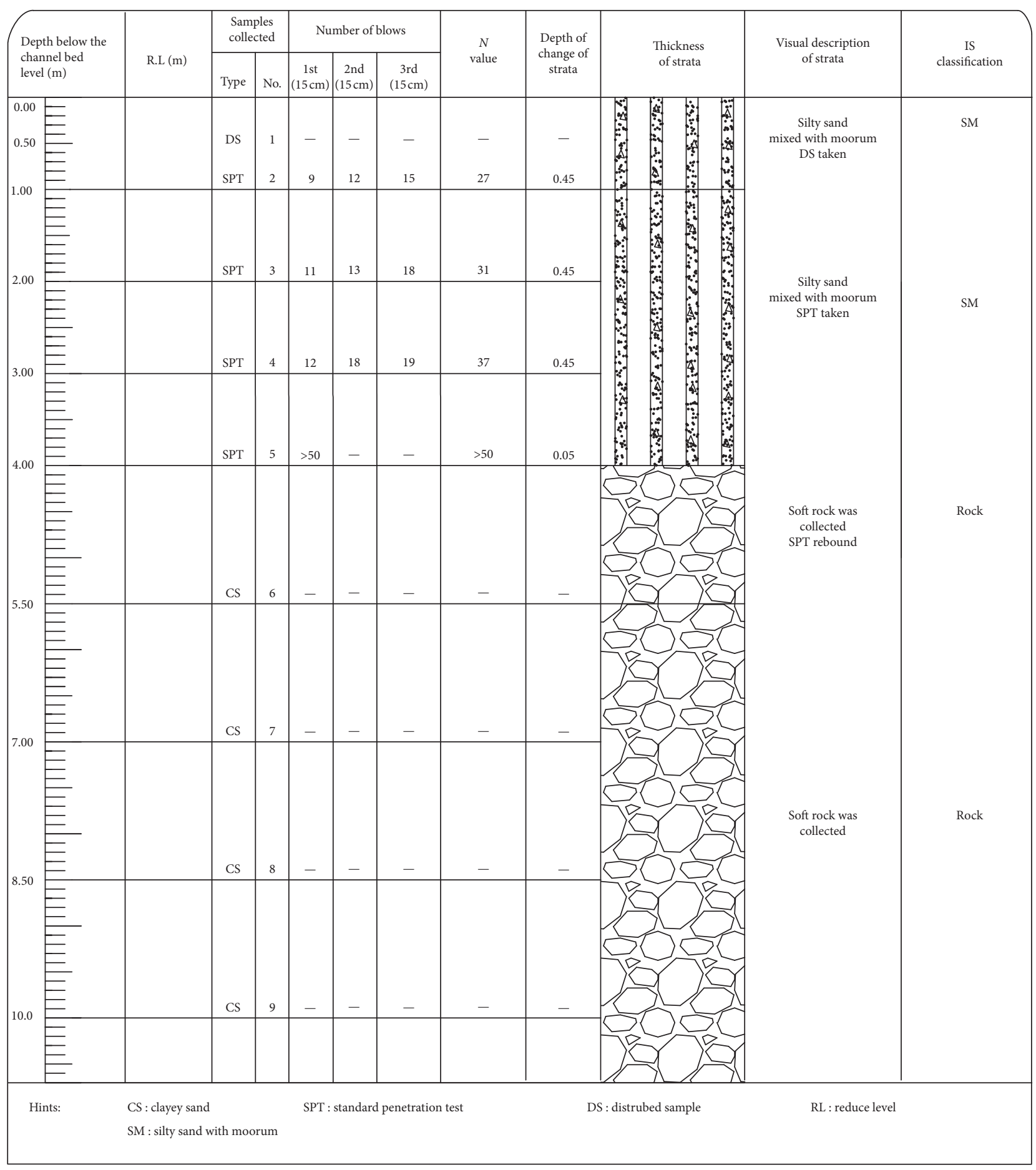

FIGURE 3: Log datasheet of borehole 3.

that nonplastic, nonexpansive silty sand mixed with moorum strata was located. DS was collected at $0.5 \mathrm{~m}$, and field $N$ value was from SPTs 32, 35, and more than 50 at $0.5 \mathrm{~m}, 1.0 \mathrm{~m}$, $2.0 \mathrm{~m}$, and $3.0 \mathrm{~m}$ respective depths. From $4.0 \mathrm{~m}$ to $10.0 \mathrm{~m}$ depth, the presence of soft rock strata was substantiated. In the 3 rd borehole sample (BH-3), nonplastic, nonexpansive silty sand mixed with moorum strata was present from $0.0 \mathrm{~m}$ to $4.00 \mathrm{~m}$ depth (Figure 3 ). DS was collected at $0.5 \mathrm{~m}$, and field $N$ value was from SPTs 27, 31, and 37 at $0.5 \mathrm{~m}, 1.0 \mathrm{~m}$,
$2.0 \mathrm{~m}$, and $3.0 \mathrm{~m}$ respective depths. This was followed by soft rock strata from $4.0 \mathrm{~m}$ to $10.0 \mathrm{~m}$ depth. The safe bearing capacity (SBC) which is the least gross pressure which will cause shear failure of the supporting soil immediately below the footing, net safe bearing capacity (NSBC) that defines net pressure that can be applied to the footing by external loads that will just initiate failure in the underlying soil which is equal to ultimate bearing capacity minus the stress due to the weight of the footing and any soil or surcharge directly above 


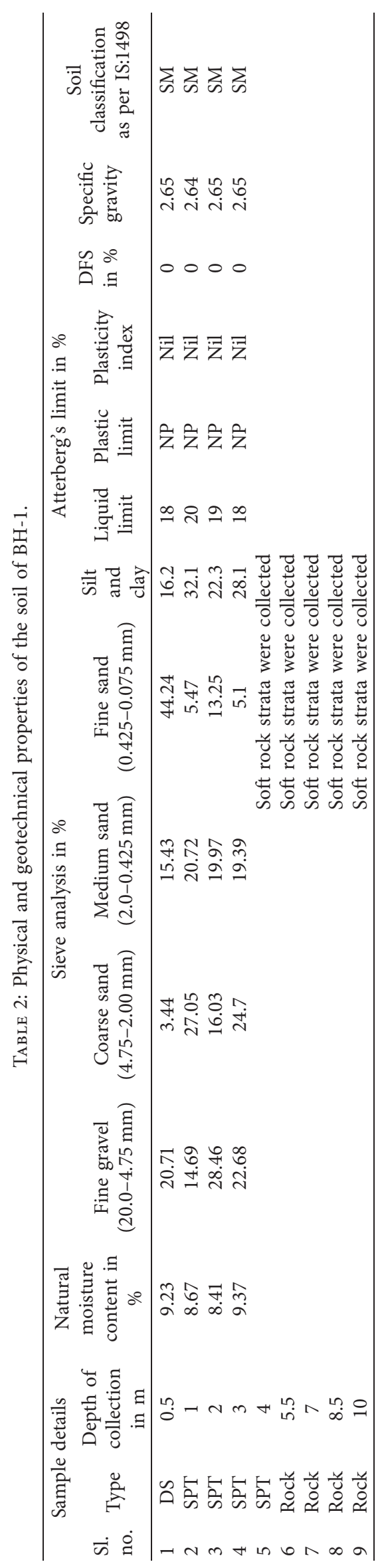




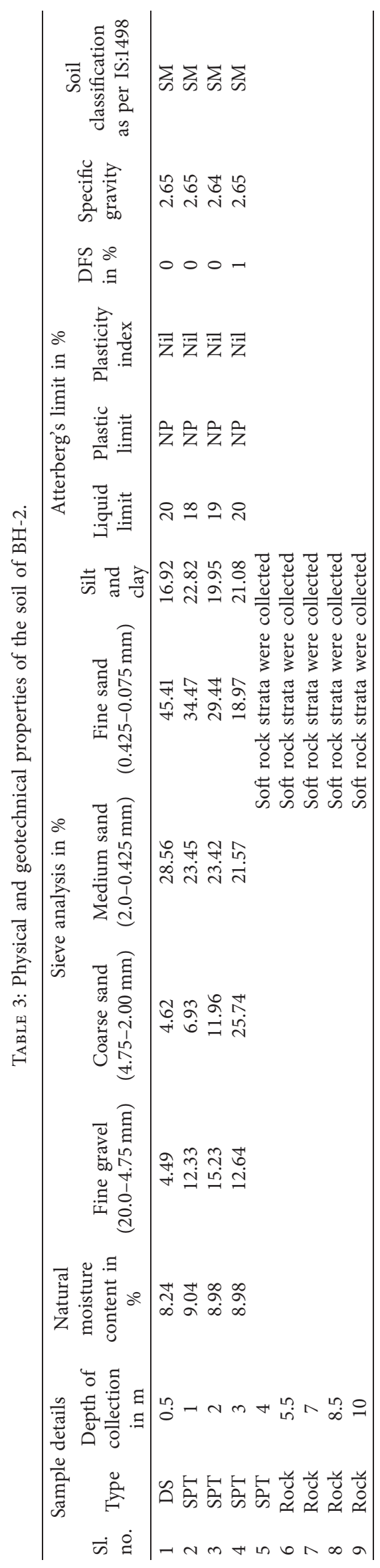




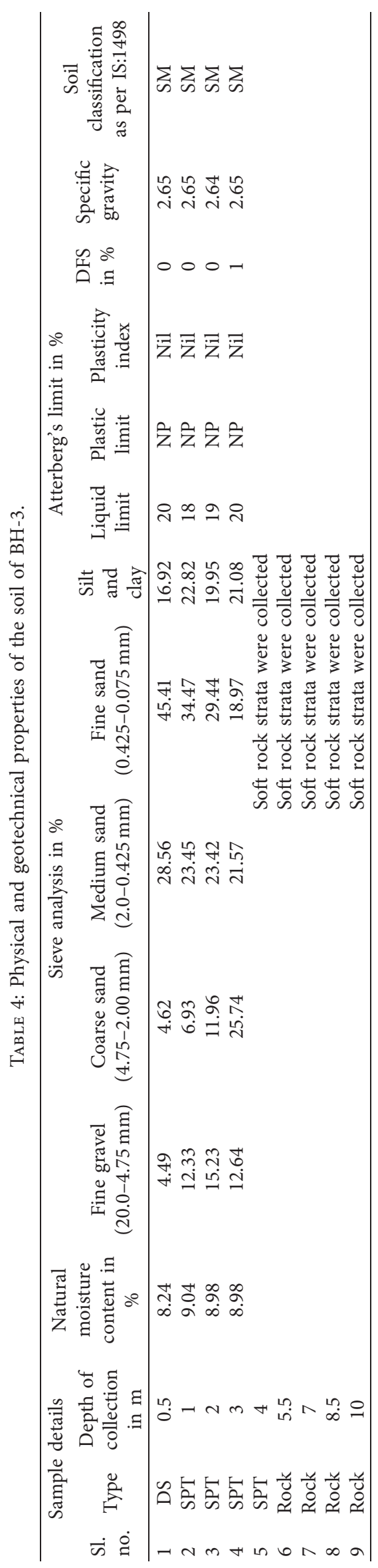


TABLE 5: CBR report of soil samples.

\begin{tabular}{|c|c|c|c|}
\hline & & Sample 1 & Sample 2 \\
\hline \multirow{6}{*}{ Engineering properties } & Maximum dry density (MDD) in $\mathrm{gm} / \mathrm{cc}$ & 1.89 & 1.86 \\
\hline & Optimum moisture content (OMC) in \% & 9.50 & 8.50 \\
\hline & CBR value (unsoaked condition) in \% & 18.4 & 20.0 \\
\hline & CBR value (in the soaked condition) in \% & 17.20 & 13.50 \\
\hline & Moisture content after 4 days soaking in \% & 11.50 & 9.65 \\
\hline & Bulk density in gm/cc & 2.1 & 2.03 \\
\hline \multirow{5}{*}{ Grain size analysis } & Fine gravel $(20 \mathrm{~mm}-4.75 \mathrm{~mm})$ in $\%$ & 7.125 & 15.625 \\
\hline & Coarse sand $(4.75 \mathrm{~mm}-2.0 \mathrm{~mm})$ in $\%$ & 4.395 & 11.61 \\
\hline & Medium sand $(2.0 \mathrm{~mm}-0.425 \mathrm{~mm})$ in $\%$ & 37.11 & 41.87 \\
\hline & Fine sand $(0.425 \mathrm{~mm}-0.075 \mathrm{~mm})$ in $\%$ & 45.77 & 26.21 \\
\hline & Silt and clay $(0.075 \mathrm{~mm}-0.001 \mathrm{~mm})$ in $\%$ & 6.35 & 4.68 \\
\hline \multirow{3}{*}{ Atterberg's limit } & Liquid limit (LL) in \% & 21 & 18 \\
\hline & Plastic limit (PL) in \% & Nil & Nil \\
\hline & Plasticity index $(\mathrm{PI})$ in \% & NP & NP \\
\hline Classification of the soil & & SP-SM & SP-SM \\
\hline
\end{tabular}

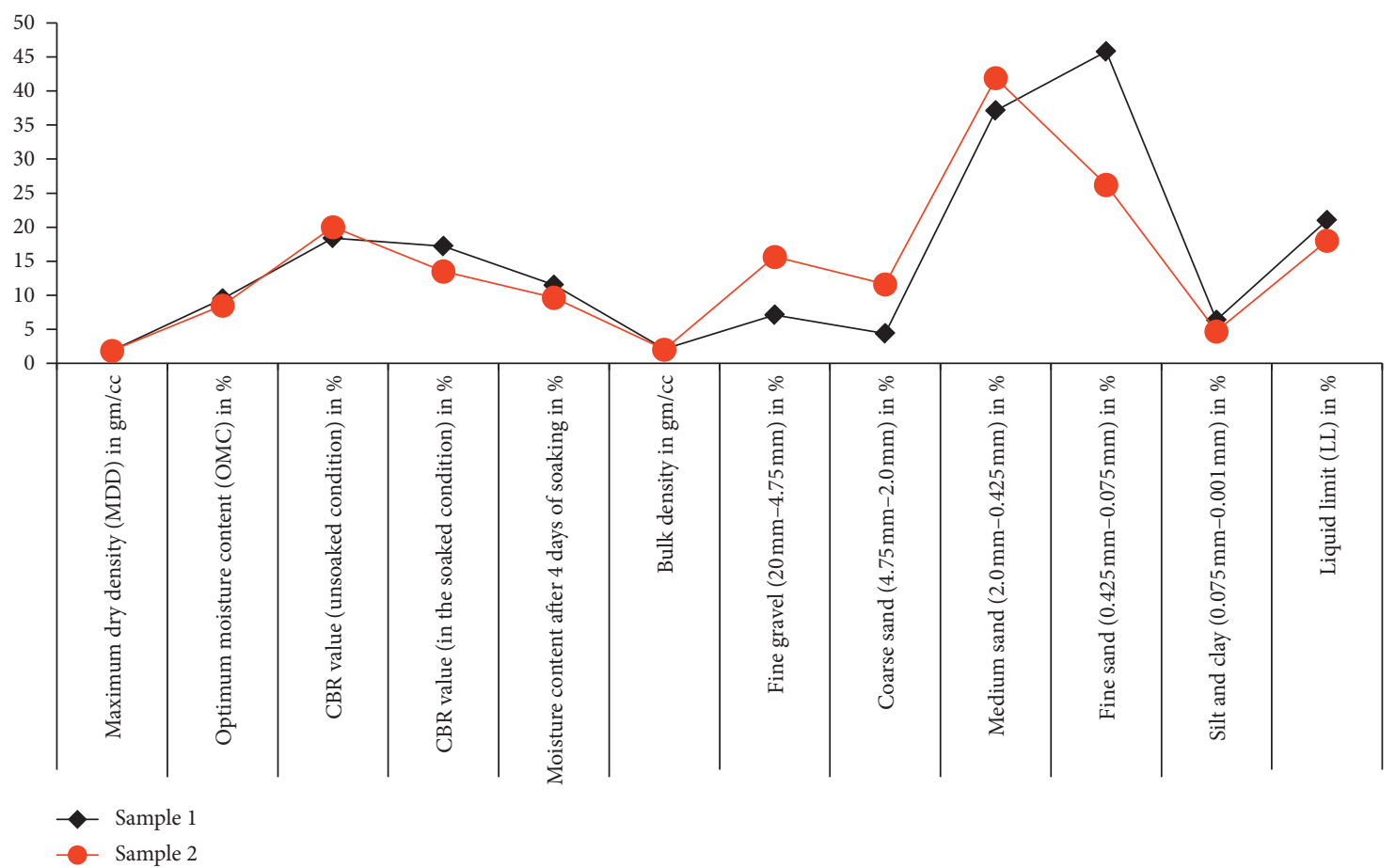

FIGURE 4: Graph of different properties of soil from the CBR report.

it, and the settlement (Table 1) have been calculated as per $[28,29]$. Using the Indian Standard Code and using the equation, accordingly, at different depths from the existing ground level, the allowable bearing capacity of $50 \mathrm{~mm}$ settlement is provided.

The physical and geotechnical properties of soil samples collected from $\mathrm{BH}-1, \mathrm{BH}-2$, and $\mathrm{BH}-3$ have been given in Tables 2-4, respectively. These tables provide details of moisture content, sieve analysis, Atterberg's limit, and differential free swell (DFS) in percentage, as well as specific gravity and classification of soil encountered during boring. It is found that up to a depth of $3 \mathrm{~m}$, sandy soil with moorum was established in all the three borehole samples. Since the DFS in all the cases is too less, it can be considered that the soil through which SPTs [30, 31] have been conducted is absolutely nonexpansive in nature and does not swell due to groundwater interaction. To support for a safe foundation, the liquid limit values add some more information.

Two sets of soil samples were taken to calculate the California bearing ratio (CBR). The tests were characterized as engineering properties, grain size analysis, and Atterberg's limit in order to classify the soil type. This test was conducted in addition to the calculations already performed from borehole samples to justify if any variation in the test results ensues. The results validate hardly any discrepancy among the two sets of results. Considering the aforementioned parameters (Table 5), a graph has been drawn so as to compare and coordinate the parameters (Figure 4). The 
TABLe 6: Determination of field density of soil and compaction result in gm/cc.

\begin{tabular}{|c|c|c|c|c|c|c|c|c|c|c|}
\hline & Test-1 & Test-2 & Test-3 & Test-4 & Test-5 & Test-6 & Test-7 & Test- 8 & Test-9 & Test-10 \\
\hline Weight of core + compacted soil in gms $(W)$ & 3082 & 3030 & 2944 & 3010 & 2946 & 3098 & 3184 & 3116 & 3168 & 3314 \\
\hline Weight of core in gms ( & 93 & 934 & 934 & 934 & 934 & 934 & 934 & 934 & 934 & 934 \\
\hline Weight of wet soil in gms $\left((W-W 1)=W_{2}\right)$ & 2148 & 2096 & 2010 & 2076 & 2012 & 2164 & 2250 & 2182 & 2234 & 2380 \\
\hline $\mathrm{CC}$ & 10 & 1021 & & & & 10 & 10 & 10 & 10 & 1021 \\
\hline Wet & 2.10 & 2.05 & 1.97 & 2.03 & 1.97 & 2.12 & 2.20 & 2.14 & 2.19 & 2.33 \\
\hline ntent $(\mathrm{MC})$ in $\%$ & 13.24 & 11.59 & 7.86 & 8.85 & 8.10 & 931 & 10.69 & 11.73 & 9.49 & 15.69 \\
\hline $\begin{array}{l}\mathrm{n} \mathrm{gm} / \mathrm{cc} \\
00) /(100+\mathrm{MC})\end{array}$ & 1.85 & 1.84 & 1.82 & 1 & 2 & 1 & 1.99 & 1.91 & 2.00 & 2.01 \\
\hline & 1.89 & & & 1.86 & 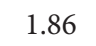 & 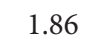 & 1. & . & 1.86 & 1.89 \\
\hline$\%$ of compaction $(D /$ lab MDD $) \times 100$ & 97.88 & 98.76 & 97.69 & 100.75 & 98.01 & 104.30 & 106.8 & 102.47 & 107.5 & 106.35 \\
\hline
\end{tabular}

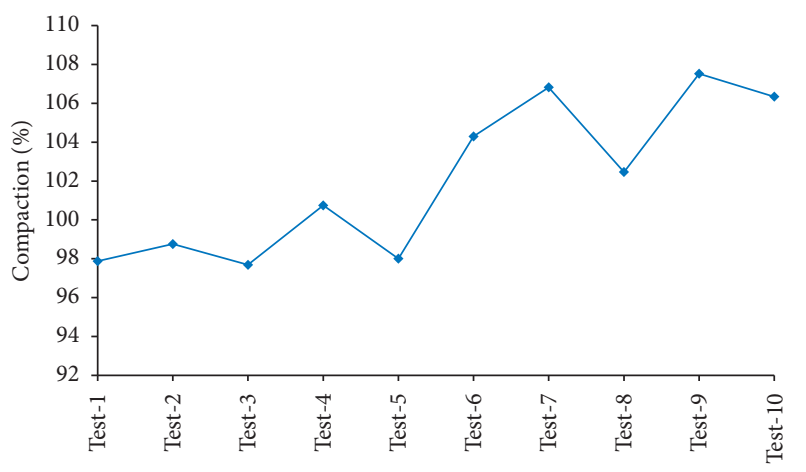

FIGURE 5: \% of compaction of different test results.

TABLE 7: Encountering water table during boring.

\begin{tabular}{lcc}
\hline Borehole no. & $\begin{array}{c}\text { Termination } \\
\text { depth in } \mathrm{m}\end{array}$ & $\begin{array}{c}\text { Water table from } \\
\text { the ground level in } \mathrm{m}\end{array}$ \\
\hline 1 & 10 & 1.4 \\
2 & 10 & 1.2 \\
3 & 10 & 1.3 \\
\hline
\end{tabular}

MDD, OMC, unsoaked CBR, bulk density, and silt and clay percentage values were evaluated and found to be very close to each other, whereas there is a huge variation in grain size analysis probably due to the origin and distribution of percentage of coarse materials in the soil.

The percentage of compactions has been calculated for ten tests. The stepwise calculation has been presented in Table 6. From the results, it is clear to conclude that the soil compaction is at a healthy stage, and groundwater interaction to this soil does not put any adverse effect or impact to swell it. These compaction parameters give a clear picture for a safe foundation at shallow depth in $\mathrm{m}$.

The percentage of compaction of all the ten tests has been compiled to generate a graph (Figure 5). The compaction factors have grown steadily from $98 \%$ and present comfortable and safe foundation criteria.

Observation of the groundwater table is important since it influences the bearing capacity of soil in different seasons. When the foundation remains submerged under water, the bearing capacity is to be calculated considering the water table correction factor. Therefore, while conducting tests during dry season, it is always necessary to enquire about the groundwater table level. The water table has been located at $1.2 \mathrm{~m}$ below NGL to $1.4 \mathrm{~m}$ below NGL (Table 7). It is clear that groundwater occurs at shallow depth in $\mathrm{m}$, and any aquifer existing at this level may be an unconfined aquifer which hardly puts any impact on the stability of the soil strata.

\section{Conclusion}

Three bore holes drilled at three different locations on the proposed line supported by two sets of soil tests for CBR engineering properties in both field and laboratory have been analysed. It has been decided that a suitable foundation can be taken at a suitable depth as per the designing aspects from the original ground level both for economical point of view and for good structural stability with respect to the type of structure. The SBC at different depths has been mentioned for structural design purpose and the suitable foundation. In the behest, it can be mentioned that sandy soil mixed with moorum which has been decayed and disintegrated from laterites is almost suitable for the construction of the shallow foundation, and as such, groundwater does not put any adverse effect such as swelling which can be a safe zone for the construction of foundation. Under the above circumstance studying all the requisite parameters, $10 \mathrm{~m}$ deep boring is enough to find out all the required parameters for the safe foundation. Enough study was accrued so that lacunae, if any, can be avoided at the time of construction.

\section{Data Availability}

The data used to support the findings of this study can be accessed from the corresponding author upon request.

\section{Conflicts of Interest}

The authors declare that they have no conflicts of interest.

\section{References}

[1] R. Katzenbach, G. Bachmann, and H. Ramm, "Combined pile raft foundation (CPRF): an appropriate solution for foundation of high-rise building," Slovak Journal of Civil Engineering (SJCE), vol. 5, pp. 19-29, 2005.

[2] A. B. Salahudeen and J. A. Sadeeq, "Evaluation of bearing capacity and settlement of foundations," Leonardo Electronic Journal of Practices and Technologies, vol. 29, pp. 93-114, 2016. 
[3] A. B. Salahudeen, T. S. Ijimdiya, A. O. Eberemu, and K. J. Osinubi, "Prediction of bearing capacity and settlement of foundations using standard penetration data in the SouthSouth geo-political zone of Nigeria," in Proceedings of International Conference on Construction Summit Nigerian Building and Road Research Institute (NBRRI), pp. 349-368, Abuja, Nigeria, January 2016.

[4] F. O. Olusola and A. Oluwatobi, "In-situ foundation characterization and design in ese odo local government area of ondo state, southwestern Nigeria," Global Journal of Engineering and Technology Advances, vol. 3, no. 2, pp. 1-18, 2020.

[5] L. Anthopoulos and P. Fitsilis, "Using classification and road mapping techniques for smart city viability realization," Electronic Journal of EGovernment, vol. 11, no. 1, pp. 326-336, 2013.

[6] S. Bhalla, Y. W. Yang, J. Zhao, and C. K. Soh, "Structural health monitoring of underground facilities - technological issues and challenges," Tunnelling and Underground Space Technology, vol. 20, no. 5, pp. 487-500, 2005.

[7] J. Chai, J. X. Liu, B. Qiu et al., "Detecting deformations in uncompacted strata by fiber Bragg grating sensors incorporated into GFRP," Tunnelling and Underground Space Technology, vol. 26, no. 1, pp. 92-99, 2011.

[8] F.-C. Lin, C. T. Victor, B. Schmandt, Z. Duputel, and Z. Zhan, "Extracting seismic core phases with array interferometry," Geophysical Research Letters, vol. 40, pp. 1049-1053, 2013.

[9] M. E. El-Hawary, "The smart grid-state-of-the-art and future trends," Electric Power Components and Systems, vol. 42, no. 3-4, pp. 239-250, 2014.

[10] H. Jiang, P. Lin, M. Qiang, and Q. X. Fan, "A labor consumption measurement system based on real-time tracking technology for dam construction site," Automation in Construction, vol. 52, pp. 1-15, 2015.

[11] K. S. Rao and K. R. Chandran, "Mining of customer walking path sequence from RFID supermarket data," Electronic Government, vol. 10, no. 1, pp. 34-55, 2013.

[12] S. Self, D. Entwisle, and K. Northmore, The Structure and Operation of the BGS National Geotechnical Properties Database, British Geological Survey, Nottingham, UK, 2012.

[13] I. Shahrour, O. Abbas, A. Abdallah et al., "Lessons from a large-scale demonstrator of the smart and sustainable city," in Happy City - How to Plan and Create the Best Livable Area for the People, H. Brdulak and A. Brdulak, Eds., Springer-Verlag, Berlin, Germany, 2016.

[14] B. M. Das and N. Sivakugan, "Settlements of shallow foundations on granular soil: an overview," International Journal of Geotechnical Engineering, vol. 1, no. 1, pp. 19-29, 2007.

[15] M. J. W. Al-Jabban, "Estimation of standard penetration test (SPT) of hilla city-Iraq by using GPS coordination," Jordan Journal of Civil Engineering (JJCE), vol. 7, no. 2, pp. 133-145, 2013.

[16] J. E. Bowles, Foundation Analysis and Design, McGraw-Hill, New York, NY, USA, 5th edition, 1996.

[17] F. H. Kulhawy and P. W. Mayne, Manual on Estimating Soil Properties for Foundation Design, Electic Power Research Institute, Palo Alto, CA, USA, 1990.

[18] F. Schnaid, Ensaios de campo e suas aplicações à Engenharia de Fundações, Oficina de textos, São Paulo, Brazil, 2000.

[19] N. O. Dago and W. Tamunonengiyeofori, "Geotechnical subsoil investigation for the design of water tank foundation," International Journal of Scientific and Research Publication, vol. 4, no. 3, pp. 1-10, 2014.
[20] IS:1892, Code of Practice for Subsurface Investigation for Foundations, Indian Standards Institution, New Delhi, India, 1979.

[21] IS:2131, Method for Standard Penetration Test for Soil, Bureau of Indian Standards, New Delhi, India, 1981.

[22] K. P. Dash, T. K. Lohani, and H. R. Behera, "Sub soil investigation and suitable type of foundation for construction of superstructure in the bank of Gangue Nallah, Bhubaneswar," International Journal of Latest Research in Science and Technology, vol. 3, no. 5, pp. 90-94, 2014.

[23] IS:2720, Methods of Test for Soils, Grain Size Analysis, Bureau of Indian Standards, New Delhi, India, 1985.

[24] IS:2720, Methods of Test for Soils, Determination of Water Content, Bureau of Indian Standards, New Delhi, India, 1973.

[25] IS:2720, Methods of Test for Soils, Determination of Specific Gravity, Sec 1 Fine Grained Soil, Bureau of Indian Standards, New Delhi, India, 1980.

[26] IS:2720, Methods of Test for Soils, Determination of Liquid and Plastic Limit, Indian Standards Institution, New Delhi, India, 1985.

[27] IS:2720, Methods of Test for Soils, Determination of Free Swell index of Soils, Bureau of Indian Standards, New Delhi, India, 1977.

[28] IS:6403, Code of Practice for Determination of Breaking Capacity of Shallow Foundations, Bureau of Indian Standards, New Delhi, India, 1981.

[29] IS:8009, Code of Practice for Calculation of Settlements of Foundations, Shallow Foundations Subjected to Symmetrical Static Vertical Loads, Bureau of Indian Standards, New Delhi, India, 1976.

[30] M. O. Karkush, M. D. Ahmed, A. A. H. Sheikha, and A. AlRumaithi, "Thematic maps for the variation of bearing capacity of soil using SPTs and MATLAB," Geosciences, vol. 10, no. 9 , p. 329, 2020.

[31] M. O. Karkush and A. N. Aljorany, "Analytical and numerical analysis of piled-raft foundation of storage tank," Lecture Notes in Civil Engineering, vol. 84, pp. 373-384, 2020. 